\title{
Dis-locating the Tale. Roberto Innocenti, Little Red Riding Hood and the Contemporary "Non-lieux"
}

\section{Giorgio Bacci}

\section{(2) OpenEdition \\ Journals}

Electronic version

URL: https://journals.openedition.org/edl/1601

DOI: $10.4000 /$ edl. 1601

ISSN: 2296-5084

\section{Publisher}

Université de Lausanne

\section{Printed version}

Date of publication: 15 September 2019

Number of pages: 99-118

ISBN: 978-2-940331-71-0

ISSN: 0014-2026

\section{Electronic reference}

Giorgio Bacci, "Dis-locating the Tale. Roberto Innocenti, Little Red Riding Hood and the Contemporary "Non-lieux" "', Études de lettres [Online], 310 | 2019, Online since 15 September 2021, connection on 22 September 2021. URL: http://journals.openedition.org/edl/1601 ; DOI: https://doi.org/10.4000/edl 1601

This text was automatically generated on 22 September 2021.

(c) Études de lettres 


\title{
Dis-locating the Tale. Roberto Innocenti, Little Red Riding Hood and the Contemporary "Non-lieux"
}

\author{
Giorgio Bacci
}

1 Roberto Innocenti, born in 1940 in Bagno a Ripoli, near Florence, is one of the most famous illustrators of the second half of the twentieth century and his work is known internationally: his books have been translated into many languages (including English, German, French, and Japanese), reaching a wide and varied audience. The award-winning illustrator is the only Italian artist to date to have received the prestigious Hans Christian Andersen Award in 2008. Marco Magnani has defined Innocenti's illustrations as "contemporary paintings" that reconcile tradition and modernity, classical systems and new approaches of representation using "fish-eye" perspective, lenticular landscape descriptions, as well as "traditional" perspective, in an intricate technical combination that makes him a great contemporary $\operatorname{artist}^{2}$. The viewer is thus faced with complex and original graphic solutions that make Innocenti's plates immediately recognizable. His style is characterized by images that are rich in realia as they anchor the old stories in familiar settings that make them modern "classics". In so doing, Innocenti does not limit himself to updating traditional fairy tales, which are often sedimented in the collective imagination, but also manages to reconcile contemporary historical dimensions and timelessness. The use of a certain photographic realism thus assumes a particular nuance, effectively succeeding in pushing its epistemological, historical and cultural characteristics to the limits ${ }^{3}$. The image conveys a sense of autonomous creation, and unsurprisingly many of Innocenti's books overturn one of the most common assumptions in the analysis of the relationship between text and image: in the case of the Italian artist, images take precedence over words, which often only serve to accompany the visual narration. It is no coincidence that Innocenti prefers short and incisive texts, leaving room for his " contemporary paintings" to tell the tale. In this context, as we will see, The Girl in Red plays a central role. 
Obviously, the complexity of his treatment of the fairy tale in a contemporary key is linked to the stylistic and conceptual wealth of Roberto Innocenti's artwork, making it particularly challenging to unpack ${ }^{4}$. What follows is an analysis of Innocenti's illustrations from the perspective of an art historian, suggesting innovative interdisciplinary readings (in particular the relationship with Gabriele Basilico's photographs that are closely linked to Marc Augé's dialogue with the non-lieux) while also hinting at the concept of " contemporariness " in relation to Innocenti himself.

\section{Innnocenti and the Concept of Contemporariness}

3 Browsing the books created by Innocenti, it quickly becomes apparent that a discussion of 'contemporariness' cannot be limited to the technical aspect of his work, but must also encompass the artist's personality in all its complexity. He was one of the first to address the issue of the Holocaust in an illustrated book intended for children and young adults (although it also proved popular among older readers as well), Rose Blanche (1985), and to deal with the concepts of non-lieux and the degradation of city spaces in The House (2009) and The Girl in Red (2012).

4 Although not strictly linked to the topic of this article, it is opportune to dwell briefly on Rose Blanche as this will clarify the idea of the contemporary artist as developed by Innocenti, helping us to understand his approach to fairy tales as an instrument of reflection on the present, as exemplified in The Girl in Red. Rose Blanche, the name of the child-protagonist and allusion to the non-violent group opposing Nazism called Die Weiße Rose $e^{5}$, is set in a village on the border between Germany and Poland through which troops are in transit. There is a nearby wood which, following the ancient tradition of the fairy tale, also marks the semantic boundary of the tale. Innocenti adopts the protagonist's perspective and through her eyes shows the reader the tragic destruction caused by war. At the beginning of the book the girl gradually becomes aware of the ongoing tragedy, passing from the deceitfully festive departure of German soldiers who are leaving for the front to the smoking ruins of the little town in the last plates. The key episode in the story is the chance discovery, by Rose Blanche, of a concentration camp at the borders of the wood, which reacquires its narrative function of being a mythical place of disenchantment. It is an initiation of life that turns into death in the final plate, in which the girl is accidentally killed by German troops near the demolished concentration camp, a historical reference to the Nazi attempt to destroy any tangible evidence of the atrocities.

Innocenti cleverly combines reality and fiction, creating interactions between different narrative levels and patterns : the precise historical documentation serves as a scaffold for an imaginary story, which addresses the dilemma of what may be shown about the Holocaust ${ }^{6}$.

Historical awareness allows us to reflect on modernity, an idea that is also at the core of The House (2009) and The Girl in Red (2012). The former tells the story of a Tuscan country house and its changes over the course of the $20^{\text {th }}$ century, from being the principal socio-familial centre until its depersonalization into a modern villa. The latter sets the traditional fairy tale of "Little Red Riding Hood" in a contemporary metropolis where social life and sustainable development have become chimeras. As such, Innocenti's engagement with modernity calls to mind Marc Augé and Claudio Parmiggiani's distinction between "improvisation" and " contemporariness". 
7 While Parmiggiani notes that the great watershed is actually located on the ridge between being and not being an artist, between the "uncritical glorification of the present and of the daily life" and the deep "tension towards the absolute moment that defines his [the artist's] freedom "7, Augé underlines (after Henri Focillon and George Kubler) that :

[...] l'œuvre, aujourd'hui comme hier, se mesure par rapport à trois paramètres :

a) Son inscription dans une histoire spécifique, l'histoire "interne ", fût-ce à titre révolutionnaire.

b) Son articulation à son temps, son existence par rapport à l'histoire "externe ", contextuelle, même si celle-ci ne se manifeste qu'à distance.Ces deux premiers paramètres définissent la pertinence d'une œuvre, pertinence aussi bien par rapport à son époque que par rapport à l'histoire de l'art.

c) Sa capacité symbolique, même si elle se manifeste avec retard.

Cette capacité symbolique, c'est son aptitude à créer un lien (intellectuel, affectif et social) avec ceux qui la découvrent. Elle définit la présence d'une œuvre ${ }^{8}$.

8 According to these criteria, particularly in relation to the "capacite symbolique" and "articulation à son temps" of the images, Innocenti's artwork is situated, in the highest sense, in the contemporary international scene : on one side dealing with some major historical themes, and on the other activating a stratified historic-critical dialogue with photography and painting. From a necessarily interdisciplinary perspective, we will now analyse the case of The Girl in Red in which Innocenti describes the adventures of a modern Little Red Riding Hood figure struggling with the pitfalls of contemporary society, including garish advertising and flashing signs that are reminiscent of American Pop Art.

\section{Denouncing contemporary non-lieux : between photography and socio-cultural history}

9 Our starting point will thus be the concept of " non-lieux" defined by Marc Augé as follows :

Si un lieu peut se définir comme identitaire, relationnel et historique, un espace qui ne peut se définir ni comme identitaire, ni comme relationnel, ni comme historique définira un non-lieu. L'hypothèse ici défendue est que la surmodernité est productrice de non-lieux, c'est-à-dire d'espaces qui ne sont pas eux-mêmes des lieux anthropologiques et qui, contrairement à la modernité baudelairienne, n'intègrent pas les lieux anciens : ceux-ci, répertoriés, classés et promus « lieux de mémoire ", y occupent une place circonscrite et spécifique9.

10 Innocenti devotes an extensive part of his illustrations to contemporary non-lieux, in particular The House and The Girl in Red, where modernity is destructive from a dual point of view : it subjects the countryside to uses and rhythms that are foreign to it and deprives the city of real social and meeting places, thus strictly connecting the concepts of contemporariness and non-lieux. In this respect, we can add further nuances to the definition of " contemporariness " by quoting Franco La Cecla :

To be contemporaries would imply at the present to consider seriously the imminent catastrophe, the world reduced to a slum, the end of the city caused by the depletion of resources, the survival problem, human society that should deal with a sustainably built environment, the redistribution of opportunities to access resources ; it would imply making every effort to ensure that the entire city will not become a place of brutal conflicts between ethnic groups, forces, gangs and crazy subjectivities ${ }^{10}$. 
11 Just a few years later, in 2012, Innocenti rewrote the story of “ Little Red Riding Hood ", setting it in a modern metropolis where the little girl, who lives in one of the anonymous suburban apartment blocks that populate cities at present, has to visit her grandmother who lives in a run-down suburb on the other side of the city.

Through the journey of Little Red Riding Hood, Innocenti describes the degradation of the city, starting from the building the girl calls home. It is a relatively recent building (fig. 1), of which the illustrator gives us a close-up : the apartments form a kind of hive consisting of many identical cells, side by side but not adjoining, each deceptively selfsufficient. The isolation and lack of communication emerge clearly; on the third floor a man is quietly preparing a barbecue, while another apartment is used as a hideout by criminals (or maybe they are thieves robbing the house), and next to them a sax player is playing on the balcony. Innocenti offers a very effective glimpse of the living and housing systems of our times, in which lack of communication and indifference reign, considering that the social system of which Augé and La Cecla speak has crumbled. While social and moral systems collapse, urban landscapes denounce the lack of convincing architectural planning, a mirror of political inadequacy. Looking at this table, it is tempting to associate the artist with the work of the great photographer Gabriele Basilico, who has long studied the suburbs. The comparison is to be understood on the basis of shared interests that led Innocenti and Basilico to develop a similar artistic sensibility regarding suburbs and big contemporary metropolises and come up with similar figurative solutions.

<Image en attente de droits>

Fig. 1 - Original drawing for The Girl in Red, 2012. Varnished tempera on paper, $35,7 \times 51 \mathrm{~cm}$. (c) Roberto Innocenti, The Creative Company, Mankato, Minnesota, USA.

Even with regard to their critical thought the two artists are comparable : on one hand Basilico says that " in the peripheries, border places par excellence, the work of great architects [...] is 'declined' ad infinitum in an unmarked production that has lost its identity, and is almost completely cleared of its original genetic code "11; on the other, Innocenti in The Girl in Red depicts " un milieu vulgaire, dégradé, sans la moindre esthétique, plein de signes d'une décadence seulement compensée par une offre colossale de marchandises, la quantité à la place de la qualité "12.

On the iconographic level, The Girl in Red's building can be compared to an anonymous building of Quarto Oggiaro, photographed by Basilico in the Seventies : we are facing a beehive and Basilico chooses a close-up, photographing just some floors, where the apartments are only distinguishable by their curtains. A sense of doom and abandonment, of dormitories, flows from this picture. However, the nodal difference between the two images resides in the use of colour, something that is absent in the black and white photograph which Basilico considered to be "more useful and tested to narrate a story, as well as more abstract and less sensitive to the event "13.

Once she leaves the house with her red cape, Little Red Riding Hood is swallowed up by an urban environment dominated by advertising images that are intrusive and overwhelming to the viewer : it is the extreme outcome of what the Italian intellectual Cesare Ratta had identified as the "museum of the poor" at the beginning of the $20^{\text {th }}$ century (foreseeing inter alia the use of advertising posters for political purposes), later described by Walter Benjamin as follows : "Printing, having found in the book a refuge 
in which to lead an autonomous existence, is pitilessly dragged out onto the street by advertisements and subjected to the brutal heteronomy of economic chaos "14.

Once again, we can find a connection between Basilico and Innocenti, albeit from different perspectives: the former in the project of documenting the city, and the latter in re-locating classic fairy tales to a contemporary urban setting. The connection is even more interesting if we keep in mind that they didn't know each other. Basilico notes that urban spaces are being transformed " into pure commercial and exhibition space. Giant advertising installations form an endless loop, framing the streets and, especially in pedestrian walkways, preventing one from seeing past the second floor of the buildings. Thus the superstructure of the commercial image prevaricates the space and camouflages it, changing its shape ${ }^{15}$. Speaking about The Girl in Red, Innocenti explains that :

L'idée directrice de ce livre consistait à placer en bas de l'image la réalité d'une urbanisation anarchique, confuse, chaotique, et en haut la publicité, c'est-à-dire la fausse vie, en laquelle nous voulons croire. Cette ville pourrait se trouver n'importe où dans le monde ${ }^{16}$.

The last two quotations unequivocally highlight the theme of globalization that paradoxically contributed to the success of The Girl in Red. The city of The Girl in Red could be Milan or Paris, but also an Asian capital, or even presage the uprising against the cutting down of the Gezi Park trees in Istanbul to make way for a shopping center ${ }^{17}$.

Turning back to the story, after having encountered mime actors, crime scenes and street musicians, the girl arrives at a contemporary wood : the mall (fig. 2) (just called The Wood by Roberto Innocenti, recalling its traditional role in the fairy tale), which is crowded with advertising and campaign posters (there's a clear reference to Berlusconi in one of them, as the prototype-product of the modern société du spectacle), shops, and even thematic playgrounds. It is a true non-lieu, literally devoted to the consumption of goods (there is an obvious reference to the nave of a church in the architectural structure, in the neo-medieval stained glass and in a sort of a cross on the bottom) and ephemeral fun, in an artificially created setting ${ }^{18}$.

$<$ Image en attente de droits>

Fig. 2 - Original drawing for The Girl in Red, 2012. Varnished tempera on paper, $36,5 \times 70 \mathrm{~cm}$. (C) Roberto Innocenti, The Creative Company, Mankato, Minnesota, USA. ๔) Roberto Innocenti, The Creative Company, Mankato, Minnesota, USA.

Having left the pitfalls and temptations of the shopping centre, Little Red Riding Hood gets lost in the streets of a semi-abandoned suburb, falling prey first to a gang of bikers, and then to a motorcyclist who scares away her assailants: the apparent Samaritan, who turns out to be the real "wolf" of the story, promises to take the child to her grandmother, but instead he will leave her near a flyover. The tables, which are technically very detailed, are once again reminiscent of Basilico's photographs. The one depicting Little Red Riding Hood on the motorbike (fig. 3) evokes 1997 photos of Paris : the slightly raised point of view determines a dynamic perception of the scene and guides the viewer's eye in an inward spiral. They draw the reader's eye into the heart of modernity, a sort of futuristic city with overlapping levels and layers: above the skyscrapers and the modern offices reflected in the windows, at the bottom, below street level, the difficult life of modern-day suburbs is depicted. Alone and lost, Little Red Riding Hood finally arrives at her grandmother's house, a poor caravan where, the reader-observer can easily imagine, she falls prey to the biker-wolf. 
$<$ Image en attente de droits>

Fig. 3 - Original drawing for The Girl in Red, 2012. Varnished tempera on paper, $23 \times 27 \mathrm{~cm}$. (c) Roberto Innocenti, The Creative Company, Mankato, Minnesota, USA.

This table is also deserving of more attention from an artistic point of view (fig. 4) : the caravan is indeed a small and melancholic structure (see for example the little Christmas tree outside the door, the clothes drying on the line) that contains significant details (the house number, the bin for separate waste collection, a vase of flowers outside the window). It is a surreal space, surrounded by roads and overshadowed by the building of a multinational : this evokes another photograph by Basilico, in which a small two-story house is the last obstacle to the advance of modernity. Melancholic elements (the house number that resists, the small garden at the entrance) coexist with the surrounding anonymity (an industrial area with skyscrapers all around it and big structures at the bottom).

<Image en attente de droits>

Fig. 4 - Original drawing for The Girl in Red, 2012. Varnished tempera on paper, $23 \times 27 \mathrm{~cm}$. () Roberto Innocenti, The Creative Company, Mankato, Minnesota, USA.

21 Finally, Innocenti offers the reader alternative endings based on the classic versions: the tragic one, with the police arriving too late (as in Perrault's version), or the happy ending with the rescue broadcast live on television (after the Brothers Grimm's version [fig. 5]). The Girl in Red, which focuses on the complex metamorphosis of the contemporary city as a modern-day wood, finds a necessary complement in The House (which would require an article of its own). This illustrated book focuses on the transitions of a Tuscan country house during the $20^{\text {th }}$ century, from the time of its first restoration to its final and recent transformation into a modern "villa". The fate of the farmhouse, which was initially well-integrated with the surrounding countryside and then transformed into a depersonalized and isolated building, captures the critique presented by Augé in his texts: a place that is anthropologically determined and qualified in accordance with a system of relationships, exchanges, and activities (in The House harvest festivals, weddings, but also hospitality offered to displaced people during the war) becomes inexorably a space "perdu entre un passé sans trace et un avenir sans forme $" 19$.

<Image en attente de droits>

Fig. 5 - Original drawing for The Girl in Red, 2012. Varnished tempera on paper, 25,2x36,3 cm. (c) Roberto Innocenti, The Creative Company, Mankato, Minnesota, USA.

\section{Conclusion : Image and Symbol}

Once more, Innocenti uses a specific example to outline a global situation: images become symbols, the artist's personal memories permeate a universally valid visual and conceptual construction.

The images are thus more intimate and compelling for the reader/viewer, who is transported into a dimension that is suspended between reality and fantasy. It is in this subtle rift that the symbol affirms itself and the image becomes universal, inviting the reader/viewer to reflect on the contemporary world and the future, which inevitably arises from revisiting and updating the past :

Toutes les rues de ce quartier devenaient des chemins qui s'enfonçaient dans la campagne vers l'Arno ou vers les collines. Je me souviens, par exemple, d'un champ 
en friche et plein de barbelés. Une fois que je passais avec ma grand-tante, j'ai vu une lettre qui flottait, prise dans un de ces fils barbelés. Je venais d'apprendre à lire et cette lettre m'attirait avec son écriture à l'encre bleue délavée par la pluie. Je l'ai prise et me suis mis à la lire lentement : elle était adressée à une femme, appelée “mon amour", et pleine de tendresse et d'allusions à la liberté. Vers la fin, j'ai lu que l'auteur de cette lettre l'invitait à vivre sa vie, et il terminait par cette phrase : “Demain je serais fusillé. " J'ai été pris d'une grande douleur et j'ai eu l'impression d'avoir profané quelque chose. Et alors, au lieu de la sauver, je l'ai laissée là, dans le vent. [...] Une fleur posée comme souvenir, comme signe ultime d'affection, de douleur pour une perte, ce sont des choses bien ancrées que nous connaissons tous. Une fleur sur du barbelé [the last image of Rose Blanche], c'est du symbolisme à l'état pur, ça n'a pas besoin d'explication, ni de traduction, en aucune langue du monde. C'est pourquoi je l'ai utilisée pour marquer un geste et un moment définitifs : un presque rien qui est pourtant une preuve authentique d'un crime monstrueux contre l'humanité ${ }^{20}$.

This last quote brings the reader back to the introduction of the article: reality transfigured into a symbol, becoming a silent witness of human affairs. A letter that speaks of a sad goodbye, carried off by the wind, becomes a flower that is a messenger of hope and rebirth after the destruction of war. In this particular case the letter becomes absolute, approaching the status of symbol as self-declaratory image, and the photographic memory of a distant fact turns into historical awareness, which in turn is a moral admonition for the future. We are faced with Innocenti's unmistakable style that makes every landscape so strangely familiar to the observer, no matter where it is located. While globalization is one of the factors that made the international success of a story like The Girl in Red possible, the " universalizing " factor of Innocenti's artwork lies rather in his visionary and poetic ability, his skill for translating the particular into the universal without compromising its historical and documentary value.

\section{BIBLIOGRAPHY}

\section{Primary Texts}

INNOCENTI, Roberto, Rose Blanche, Neuchâtel, Édition Script, 1985 ; Mankato, Minnesota, Creative Education, 1985.

-, The House, Mankato, Minnesota, Creative Editions, 2009.

-, La mia vita in una fiaba, con Rossana Dedola, Pisa-Cagliari, Della Porta Editori, ebook 2014

(2012).

-, The Girl in Red, Mankato, Minnesota, Creative Editions, 2012.

\section{Secondary Texts}

AUGÉ, Marc, Non-lieux. Introduction à une anthropologie de la surmodernité, Paris, Éditions du Seuil, 1992. 
-, L'impossible voyage. Le tourisme et ses images, Paris, Rivages poche, « Petite bibliothèque », 1997.

-, Où est passé l'avenir ?, Paris, Éditions du Seuil, 2011.

BASILICO, Gabriele, Architetture, città, visioni. Riflessioni sulla fotografia, a cura di Andrea Lissoni, Milano, Bruno Mondadori, 2007.

BECKETT, Sandra, Red Riding Hood for All Ages : A Fairy-Tale Icon in Cross-Cultural Contexts, Detroit, Wayne State University Press, 2008.

BENJAMIN, Walter, Einbahnstraße, Berlin, Ernst Rowohlt Verlag, 1928.

-, One-Way Street and Other Writings, London, NLB, 1979.

BOtTIGHEIMER, Ruth B., Grimms' Bad Boys and Bold Boys. The Moral and Social Vision of the Tales, New Haven, Yale University Press, 1987.

DEDOLA, Rossana, INNOCENTI, Roberto, Le conte de ma vie : entretiens avec Roberto Innocenti, Paris, Gallimard, 2015.

Dentro il dettaglio. Le illustrazioni di Roberto Innocenti, a cura di Hamelin Associazione Culturale, Siena, Al.Sa.Ba. Grafiche, 2006.

DIDI-HUBERMAN, Georges, Images malgré tout, Paris, Les Éditions de Minuit, 2004.

Focillon, Henri, Vita delle forme seguito da Elogio della mano, prefazione di Enrico Castelnuovo, Torino, Einaudi, 2002 (Paris, Presses universitaires de France, 1943).

HENNARD DUTHEIL DE LA ROCHÈRE, Martine, DASEN, Véronique (éds), Des Fata aux fées : regards croisés de l'Antiquité à nos jours, Études de lettres, 289 (2011/3-4).

HENNARD DUTHEIL DE LA ROCHÈRE, Martine, LATHEY, Gillian, wOZNIAK, Monika (eds), Cinderella across Cultures. New Directions and Interdisciplinary Perspectives, Detroit, Wayne State University Press, 2016.

JOOSEn, Vanessa, LATHEY, Gillian (eds), Grimms' Tales around the Globe. The Dynamics of their International Reception, Detroit, Wayne State University Press, 2014.

LA CECLA, Franco, Contro l'architettura, Torino, Bollati Boringhieri, 2008.

KRESS, Gunther, VAN LEEUWEN, Theo, Reading Images. The Grammar of Visual Design, New YorkLondon, Routledge, 2006 (1996).

KUBLER, George, La forma del tempo. La storia dell'arte e la storia delle cose, con una nota di Gaetano Previtali, Torino, Einaudi, 2002 (Yale University Press, 1972).

MAGNANI, Marco, “ Quadri contemporanei ”, in Id., 3 scritti sull'illustrazione, a cura di Paola Pallottino, Lugano, Pagine d'Arte, 2005, p. 45-69.

NODELMAn, Perry, Words about Pictures. The Narrative Art of Children's Picture Books, Athens and London, The University of Georgia Press, 1988.

PALLOTTINO, Paola, “ Instead I find myself in the figures... The civil illustration of Roberto Innocenti ", in Le immagini della fantasia. Mostra Internazionale d'Illustrazione per l'Infanzia, exhibition catalogue, a cura di Monica Monachesi, Verona, Grafiche AZ, 2012, p. 27-33.

PARMIGGIANI, Claudio, Una fede in niente ma totale, a cura di Andrea Cortellessa, prefazione di JeanLuc Nancy, Firenze, Le Lettere, 2010.

Roberto Innocenti. Le prigioni della storia, catalogo della mostra, a cura di Paola Vassalli, Michèle Cochet, Bologna, Grafis Edizioni, 1989. 
STONE, Kay, Some Day Your Witch Will Come, Detroit, Wayne State University Press, 2008.

ZIPES, Jack, Happily Ever After. Fairy Tales, Children, and the Culture Industry, London, Routledge, 1997.

-, When Dreams Came True. Classical Fairy Tales and their Tradition, New York \& London, Routledge, 2007.

\section{NOTES}

1. With thanks to Nicolas Nicolaides.

2. Magnani observes: "The modern eye accepts as conforming to the optical datum, when it is the machine proposing it, any perspective distortion: Innocenti gets the necessary conclusions (see the fish-eye effect in the table with Pinocchio hanging from the oak). We have again that fascinating, topical cross between archaism and contemporaneity, which we mentioned before : exactly through the machine, he often renews for us the ancient systems of representation (the vertically, late antique and Byzantine perspective, the curve classical perspective, the 'cavaliere' perspective). " (M. Magnani, “Quadri contemporanei ”, p. 51 sq. ; translation mine).

3. On this topic, see P. Nodelman, Words about Pictures, and G. Kress, T. van Leeuwen, Reading Images.

4. See R. Bottigheimer, Grimms' Bad Girls and Bold Boys ; J. Zipes, Happily Ever After ; id., When Dreams Came True; K. Stone, Some Day Your Witch Will Come; M. Hennard Dutheil de la Rochère, V. Dasen, Des Fata aux fées; M. Hennard Dutheil de la Rochère et al., Cinderella across Cultures. Studies specifically devoted to Little Red Riding Hood notably include S. Beckett, Red Riding Hood for All Ages.

5. The group, formed by Christian students, opposed the Nazi regime by developing non-violent strategies between June 1942 and February 1943, when its members were arrested and condemned to death.

6. It is indeed very significant that the date of publication, 1985, was the same year in which Claude Lanzmann's nine-and-a-half-hour film-documentary Shoah was released in cinemas. The director rejected archival images, deciding to focus only on new footage of Holocaust sites and contemporary interviews with survivors, a choice that fits neatly within the debate on the admissibility (or not) of images as documentary sources and historical aids for an understanding of the Holocaust (on this topic, see G. Didi-Huberman, Images malgré tout). This approach is diametrically opposed to Alain Resnais's decision to use documentaries and photos shot during the Liberation of the camps in his 1955, thirty-two-minute-long Nuit et Brouillard.

7. C. Parmiggiani, Una fede in niente ma totale, p. 14 sq., translation mine. I have provided translations for Italian and German quotations, but not for the French ones.

8. M. Augé, Où est passé l'avenir ?, p. 55 sq. See G. Kubler, La forma del tempo and H. Focillon, Vita delle forme seguito da Elogio della mano.

9. “Un monde où l'on naît en clinique et où l'on meurt à l'hôpital, où se multiplient, en des modalités luxueuses ou inhumaines, les points de transit et les occupations provisoires (les chaînes d'hôtels et les squats, les clubs de vacances, les camps de réfugiés, les bidonvilles promis à la casse ou à la pérennité pourrissante), où se développe un réseau serré de moyens de transport qui sont aussi des espaces habités, où l'habitué des grandes surfaces, des distributeurs automatiques et des cartes de crédit renoue avec les gestes du commerce 'à la muette', un monde ainsi promis à l'individualité solitaire, au passage, au provisoire et à l'éphémère, propose à l'anthropologue comme aux autres un objet nouveau dont il convient de mesurer les dimensions inédites avant de se demander de quel regard il est justiciable " (M. Augé, Non-lieux, p. 54 sq.).

10. F. La Cecla, Contro l'architettura, p. 42.

11. G. Basilico, Architetture, città, visioni, p. 116. 
12. R. Dedola, R. Innocenti, Le conte de ma vie, p. 115.

13. G. Basilico, Architetture, città, visioni, p. 100.

14. W. Benjamin, Einbahnstraße, p. 28, cited from W. Benjamin, One-Way Street and Other Writings, p. 62.

15. G. Basilico, Architetture, città, visioni, p. 117.

16. R. Dedola, R. Innocenti, Le conte de ma vie, p. 110.

17. On the topic of globalization and fairy tales, see V. Joosen, G. Lathey, Grimms' Tales around the Globe.

18. There is here an astonishing similarity with the Center Parcs' description by M. Augé : "La bulle de Center Parcs, c'était, il est vrai, autre chose : un lieu de délices et de repos, une eau toujours chaude, une végétation luxuriante, les tropiques en toute sécurité, à deux pas des cafésrestaurants et du bon air normand. La brochure que m'envoya Center Parcs à ma demande était très détaillée, tout à fait attrayante, bien illustrée et intelligemment rédigée. L'idéal, disait-elle, 'ce serait une île tropicale bordée de sable blanc, baignée d'une eau bleue et chaude, couverte de cocotiers'. Mais l'idée, c'était le 'Paradis aquatique tropical', un lagon de céramique peu profond, où chacun trouvait sa place et pouvait barboter en toute sécurité, quelques vaguelettes déclenchées, tous les quarts d'heure par une machinerie sans surprise, une fausse cascade, une fausse rivière, des rapides roulant le long de toboggans plastifiés, et des jacuzzis dans lesquels on pouvait s'allonger en fermant les yeux. Ce que la brochure opposait à l'idéal, ce n'était donc pas le réel mais le réel remodelé par l'intelligence et l'imagination : l'idée " (L'impossible voyage, p. 52 sq.).

19. M. Augé, L'impossible voyage, p. 110.

20. R. Dedola, R. Innocenti, Le conte de ma vie, p. 21 sq.

\section{ABSTRACTS}

Roberto Innocenti's illustrations have been qualified as "contemporary paintings" by Marco Magnani, inasmuch as they reconcile modernity and tradition, classical systems and new approaches to representation. This article focuses on Innocenti's visual take on "Little Red Riding Hood " in The Girl in Red (2012), in order to highlight some of its iconographic references, as well as their social and philosophical implications. Innocenti indeed sheds light on the living and housing systems of our times, characterised by indifference, isolation and lack of communication according to anthropologists Marc Augé and Franco La Cecla. In this respect, they evoke the photographic work on suburbia done by the great photographer Gabriele Basilico ${ }^{1}$.

Marco Magnani décrit les illustrations de Roberto Innocenti comme des «peintures contemporaines ", en ce sens qu'elles concilient tradition et modernité, systèmes classiques et nouvelles approches de la représentation. Mon article développe cette idée en mettant en évidence certaines références iconographiques, sociales et philosophiques dans The Girl in Red (2012). À partir du conte du « Petit Chaperon rouge », Innocenti offre un commentaire sur les modes de vie et d'habitat de notre époque où règnent le manque de communication et l'indifférence, des caractéristiques qui témoignent de l'effondrement du système social établi par les anthropologues Marc Augé et Franco La Cecla. L'œuvre d'Innocenti évoque ainsi celle du 
grand photographe Gabriele Basilico qui a réalisé un important travail documentaire sur la banlieue.

\section{AUTHOR}

\section{GIORGIO BACCI}

university of Florence 